\title{
CONTRIBUTION TO BRYOPHYTE FLORA OF CROATIA: NEW FINDING OF RARE AQUATIC MOSS FISSIDENS FONTANUS (BACH. PYL.) STEUD. IN LAKE VISOVAC (KRKA NATIONAL PARK)
}

\author{
Vedran Šggota ${ }^{1}$, Ivan Gulin ${ }^{2}$, Anja Rimac ${ }^{1}$ \& Antun Alegro ${ }^{1, *}$ \\ ${ }^{1}$ Department of Botany, Faculty of Science, University of Zagreb, Marulićev trg 20/II, 10000 Zagreb, Croatia \\ ${ }^{2}$ Lozovac 7a, 22000 Šibenik, Croatia
}

Šegota, V., Gulin, I., Rimac, A. \& Alegro, A.: Contibution to bryophyte flora of Croatia: new finding of rare aquatic moss Fissidens fontanus (Bach. Pyl.) Steud. in Lake Visovac (Krka National Park). Nat. Croat. Vol. 28, No. 1, 63-72, 2019, Zagreb.

The rare bryophyte species Fissidens fontanus was found within the course of a comprehensive field study of the aquatic flora and vegetation of Lake Visovac (Krka National Park). This is the second record of this species in Croatia after the recent discovery in the Trepča River. The species grows among rich macrophyte vegetation, forming small patches up to $2.5 \mathrm{~m}$ in depth. Due to its rareness and plausible threats, we assessed F. fontanus as critically endangered in Croatia.

Key words: rare moss, critically endangered species, Southeastern Europe

Šegota, V., Gulin, I., Rimac, A. \& Alegro, A.: Prilog mahovinskoj flori Hrvatske: novo nalazište rijetke vodene mahovine Fissidens fontanus (Bach. Pyl.) Steud. u Visovačkom jezeru (Nacionalni park Krka). Nat. Croat. Vol. 28, No. 1, 63-72, 2019, Zagreb.

U sklopu sveobuhvatnog terenskog istraživanja vodene flore i vegetacije jezera Visovac (Nacionalni park Krka) otkrivena je rijetka mahovina Fissidens fontanus. Ovo je drugi nalaz te vrste u Hrvatskoj, nakon što je nedavno otkrivena u rijeci Trepči. Vrsta je rasla u malim hrpicama do 2,5 $\mathrm{m}$ dubine, među bogatom makrofitskom vegetacijom. Zbog svoje rijetkosti i mogućih prijetnji vrstu $F$. fontanus smatramo kritično ugroženom.

Ključne riječi: rijetka mahovina, kritično ugrožena vrsta, Jugoistočna Europa

\section{INTRODUCTION}

Although Croatia is bryologically one of the most explored countries of the former Yugoslavia and Southeastern Europe (SABovljević et al., 2011), the data are to a large extent spatially and temporally biased (ALEGRo \& ŠEGOTA, 2019). Starting in the first decades of the $19^{\text {th }}$ century, the research was at its peak of intensity at the turn of the $19^{\text {th }}$ and the $20^{\text {th }}$ century, to be intensified again in the $1950 \mathrm{~s}$ and 1960s, followed by the almost complete lack of any bryological work until 2009 (Alegro et al., 2012). Thenceforward, during the last decade, 58 new taxa were discovered as new for Croatia, mainly owing to cooperation between the Hungarian Natural History Museum and the University of Zagreb, (BLOCKeEL et al., 2009, Ellis et al., 2012a, 2012b, 2014, 2015, 2016, 2017, 2018; PAPP \& SAbovluević, 2009; KöcKinger et al., 2012; PApp et al., 2013a, 2013b, 2013c; Alegro et al., 2014, 2015, 2018a, 2018b, 2019; SABovljević et al., 2018).

\footnotetext{
* corresponding author (antun.alegro@biol.pmf.hr)
} 
In addition, a publically available database with geocoded spatio-temporal data has been established in order to summarise all historical literature and herbarium data (AlEGRO \& ŠEGOTA, 2019). However, despite considerable progress in knowledge of the diversity and distribution of Croatian bryophytes in the last decade, a great shortage of data is still evident.

The main objective of this paper is to provide further additions to the inventory of bryophytes in Croatia by presenting the new locality of Fissidens fontanus (Bach. Pyl.) Steud., which is extremely rare in Southeastern Europe.

\section{MATERIAL AND METHODS}

In summer 2018, during five field surveys, the line transect sampling method was applied for vegetation mapping of Lake Visovac. In total 21 transects were made from a boat, perpendicularly to the shore. The sampling was performed down to the depth at which aquatic vegetation ceases to appear (at a maximum depth of $17 \mathrm{~m}$ ). Extendable rakes were used for sampling the vegetation in shallow water, while a sampling rake (two metal leaf rakes bolted back-toback, handles removed and replaced with a rope), and a sampling grab were used to collect vegetation from deeper parts of the lakes (STElzer \& Schneuder 2001, CENT/TC 230, 2007). Simultaneously, the lake depth was measured using another rope and the coordinates were recorded using Garmin e-trex GPS device. Bryophyte taxa were sampled and stored within the plastic containers, not preserved, but identified in fresh condition using SMITH (2004) and Frey et al. (2006). Nomenclature follows Ros et al. (2013), applied in AleGro \& ŠEGOTA (2019). Afterwards, the bryophytes were dried and placed within the paper envelopes and stored at the ZA collection (THIERs, 2019) where they were digitized within the Flora Croatica Database (ALEGRO \& ŠEGOTA, 2019) with all metadata publically available via the virtual herbarium (REŠETNIK \& ŠEGOTA, 2019).

\section{Study area}

Lake Visovac is situated in Mediterranean Croatia, in Central Dalmatia, within the Krka National Park (Fig. 1). This natural lake is a result of tufa-formed barriers - Roški slap (upstream) and Skradinski buk (downstream) and represents the largest extension of the Krka River (Mihaljević et al., 2001; Špoljar et al., 2005). It encompasses an area of $7.9 \mathrm{~km}^{2}$ with a maximal depth of $55 \mathrm{~m}$, however in the narrower sense the lake encompasses only the water body around the islet of Visovac. The lake is a monomictic system characterised by a relatively high input of fresh water from the Krka River, and to a lesser extent of the tributary Čikola River and torrent waters from surrounding landscape (CIGLENEČKI-JUšrć et al., 2015). 


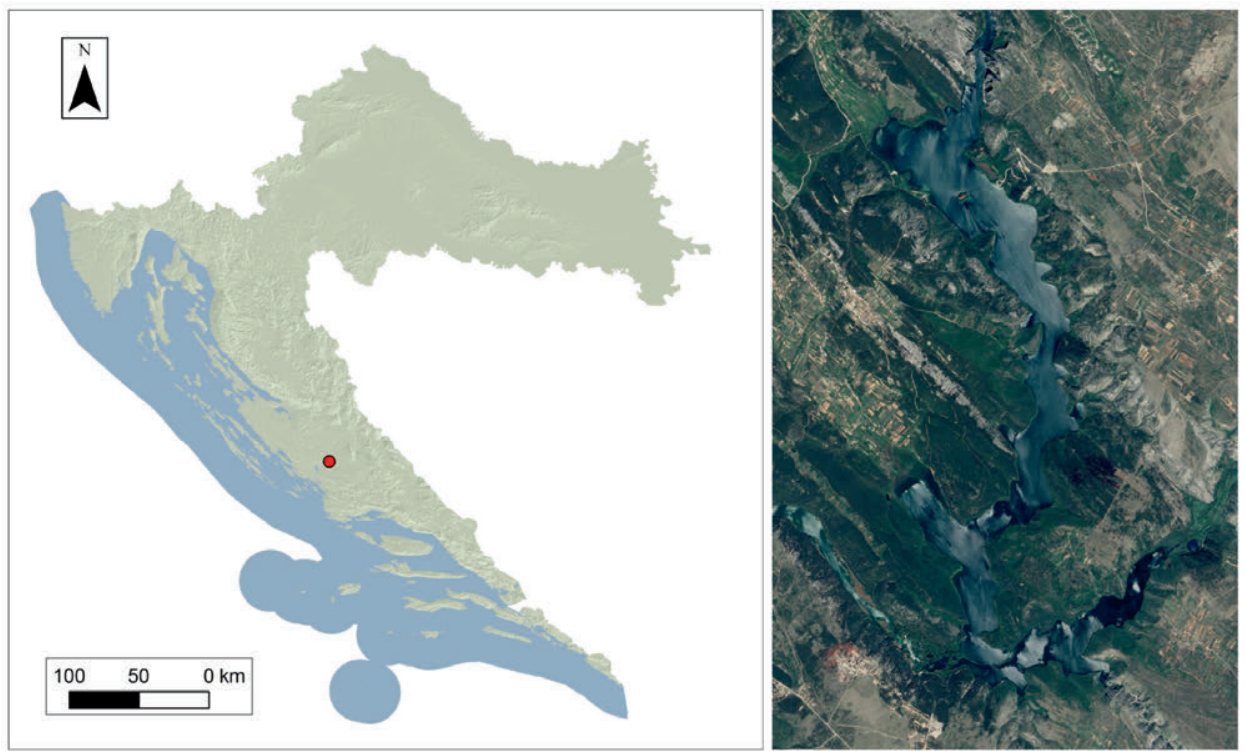

Fig. 1. Geographical position (left) and shape of Lake Visovac (Google Earth) (right).

\section{RESULTS AND DISCUSSION}

The dominant aquatic vegetation of Lake Visovac is composed of vascular flora in the shallow zone (down to $6 \mathrm{~m}$ depth) and charophytes in the deeper zone (from 6 to maximum $17.5 \mathrm{~m}$ depth) (Fig. 2).

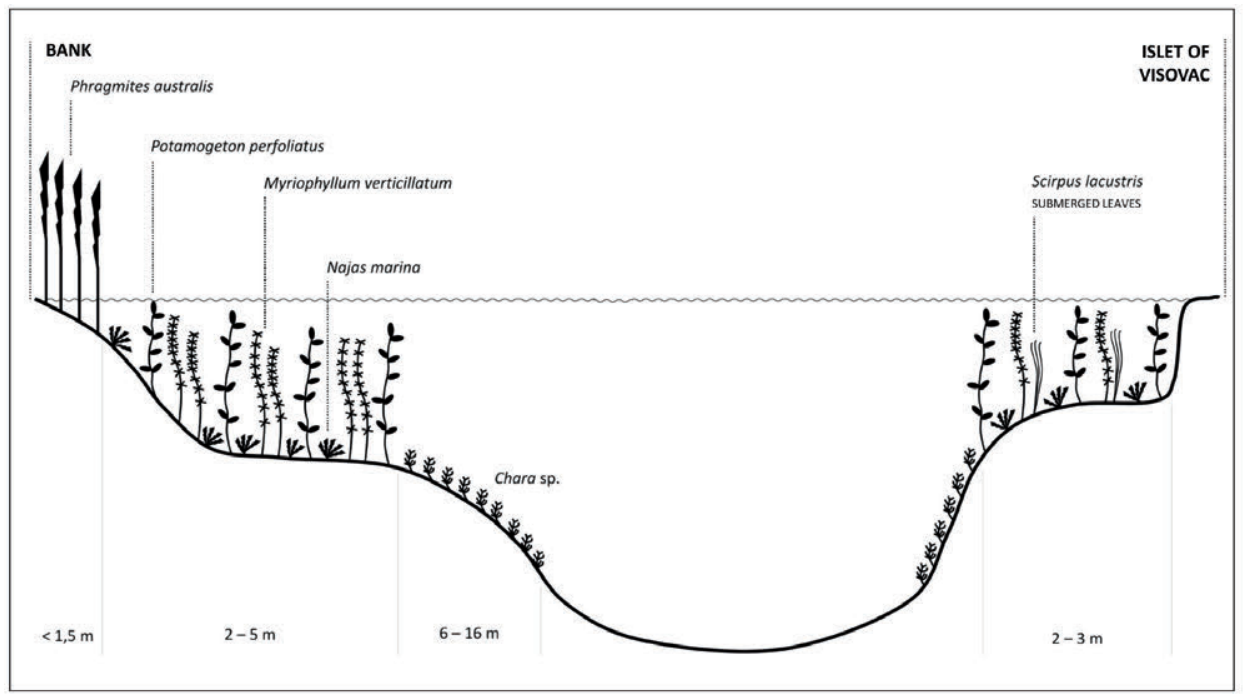

Fig. 2. Typical vegetation profile of Lake Visovac. 
Bryophytes are rarely represented in lake vegetation, not forming any particular vegetation belt. Only two bryophyte species were found, occasionally intermixed with other vegetation. Fontinalis antipyretica Hedw., a common aquatic moss of the streams and stagnant water in Croatia (AlEGRO \& Š EGOTA, 2019), was found within nine transects, mostly in shallow water (less than two meters deep), generally in small patches. Three larger stands were recorded in northern, northwestern and southwestern parts of the lake, not forming a clear vegetation belt.

An even more interesting finding was the discovery of Fissidens fontanus, recorded only at two sites, near the western shore of the lake (Fig. 3). At the first site $\left(43,859472^{\circ} \mathrm{N}, 15,969000^{\circ} \mathrm{E}\right)$, the species was found at depth of less than one meter, intermixed with Fontinalis antipyretica, Myriophyllum spicatum L., Myriophyllum verticillatum L. and a submerged form of Scripus lacustris L. At the second site $\left(43,857861^{\circ} \mathrm{N}, 15,971556^{\circ} \mathrm{E}\right)$, it was found at a depth of $2.5 \mathrm{~m}$, in the midst of Potamogeton perfoliatus L., Myriophyllum verticillatum L., Nuphar lutea Sibth. et Sm., Najas marina L., Chara spp. and a submerged form of Scripus lacustris L. In both localities the species was found in very small populations containing only a few plant shoots. The specimens from the second locality are deposited in the ZA collection under inventory number ZA53232.

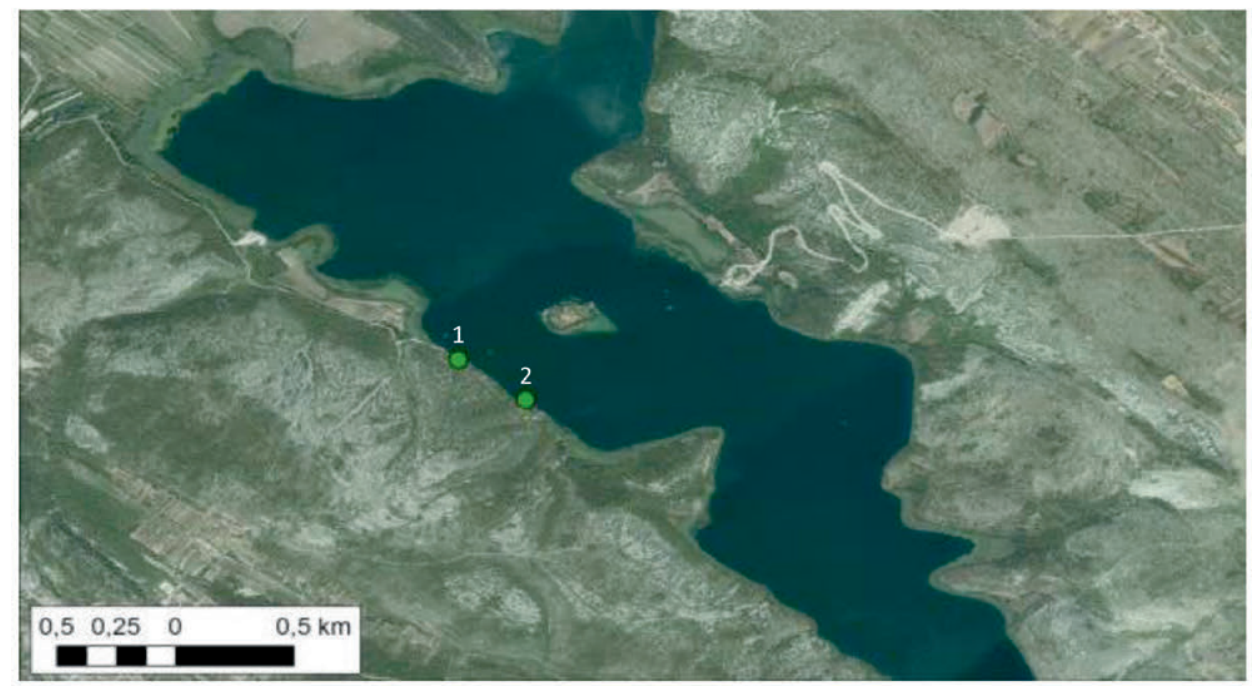

Fig. 3. Finding locations of Fissidens fontanus in Lake Visovac.

F. fontanus is flaccid, with much-branched shoots up to $3 \mathrm{~cm}$ long. The shoots appear flattened, with long, narrow leaves in 2 rows on the stem. Each leaf is up to $5 \mathrm{~mm}$ long and about 10 times as long as wide, with unbordered margins. It is easily distinguishable from other congeneric species: it lacks a central strand in the stem (thus sometimes included in the separated genus Octodiceras), the sheathing lamina reaches less than $1 / 3$ of total leaf length, and it has immersed an capsule without stomata (Fig 4.) (Privitera \& Puglisi, 1994; Smith, 2004; Erzberger, 2016). 


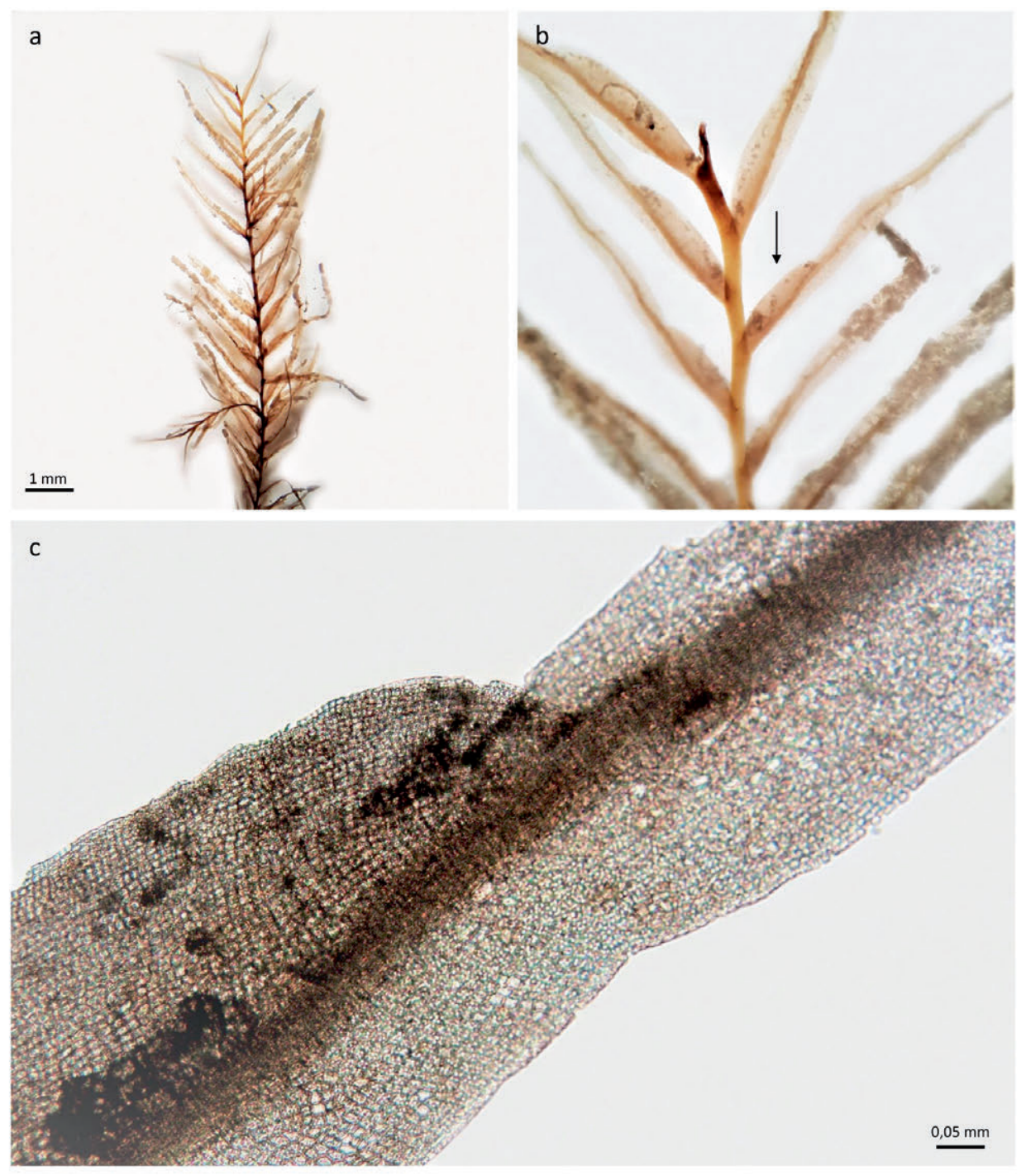

Fig. 4. Morphological features of the Fissidens fontanus specimens from Lake Visovac: a - habitus, $\mathrm{b}$ - leaves with sheathing lamina marked with an arrow, c - details of the sheathing lamina (Photo N. Koletić).

Fissidens fontanus is a European Temperate species (Hill \& Preston, 1998) occurring from the Mediterranean to Northern Europe (Sмiтh, 2004; Frey et al., 2006). It was recorded in Great Britain, Ireland, Denmark, Finland, Sweden, Estonia and Latvia in the North, in Belgium, Luxemburg, Netherlands, Switzerland, Austria, Germany, Czech Republic and Poland in Central Europe, while in the Mediterranean it is known from Portugal, Spain, France, Italy and the larger islands, Sardinia, Sicily and Madeira (HodgetTs, 2015). Boros (1968) described F. 
fontanus as a species to be expected in Hungary, however, it was hitherto searched for with no result (ERZBERGER, 2016). The species is extremely rare or, more likely, under recorded in Southeastern Europe (SABovljević et al., 2008), until recently known only from Bulgaria and Romania (NATcheva et al., 2006, StefănuȚ \& Goia, 2012). More recently, it has been recorded on Lesbos Island in Greece (BLOcKeEL \& NiEuwкоop, 2016) and in Montenegro (ANĐić et al., 2018). Interestingly, DülL et al. (1999) provide a record from Slovenia, however this was somehow overlooked in the Slovenian checklist (MARTINčič, 2003) and all following European checklists (e.g. Ros et al., 2013, HodgetTs, 2015). Regarding Croatia, the species was very recently found in the Trepča River (Banovina Region, central Croatia), representing the first Croatian record of this moss (Alegro et al., 2019).

In Lake Visovac $F$. fontanus formed very small patches, each containing only a few plant shoots. Similarly, the only two known populations in Montenegro, recently discovered in the Sitnica and Cijevna rivers, covered only a few square centimetres each (AnĐrć et al., 2018). One population of F. fontanus in Lake Visovac was growing intermixed with Fontinalis antipyretica, also observed in the Cijevna River (Montenegro), where those two species grow together on lime-containing conglomerate rocks (ANĐić et al., 2018). However, in the Trepča River (Croatia), $F$. fontanus grows in a rather rich aquatic moss community, associated not only with Fontinalis antipyretica but also with several other aquatic moss species such as Cinclidotus riparius (Host ex Brid.) Arn., Leptodictyum riparium (Hedw.) Warnst. and Rhynchostegium riparioides (Hedw.) Cardot (Alegro et al., 2019). This bryophyte community (Octodiceratetum juliani (W. Koch 1936) Krusenstjema 1945 from alliance Fontinalion antipyreticae W. Koch 1936 and class Fontinaletea antipyreticae Hiibschmann 1957) was recorded previously in other countries as well (Hübschmann, 1986; Nebel \& Philippi, 2000).

The species usually grows in clean to moderately polluted rivers and can tolerate a certain amount of pollution (Neumayr, 1971; Smith, 2004; Erzberger, 2016). This was observed previously in the Trepča River, where a significant amount of cyanobacteria from the Oscillatoriales group was found, suggesting moderately polluted conditions (Alegro et al., 2019). Two main threats were detected in Lake Visovac: the increased inflow of nutrient rich water from the city of Knin and a significant impact of boat anchoring on the vegetation cover of the lake.

Conducting a multiannual project of surveillance of water bodies throughout the whole Croatia, comprising several hundreds of rivers, streams, channels, lakes and reservoirs, we are able to conclude that $F$. fontanus is an extremely rare species in Croatia. According to the available data and following the latest criteria (IUCN, 2017), Criterion D (a very small or restricted population with fewer than 50 mature individuals) could be applied for the evaluation of $F$. fontanus; thus we propose that it should be classified as critically endangered $t$ the national level. The same category is assigned to the species in Bulgaria (NAtcheva et al., 2006) and Romania (StEFĂNuT̃ \& Goia, 2012), whereas it is considered endangered in Latvia, vulnerable in Estonia, Ireland, Luxemburg, Poland and Switzerland and near threatened in the Czech Republic and Finland (HodgetTs, 2015). 


\section{ACKNOWLEDGMENTS}

The authors are grateful to Public Institution Krka National park for enabling the field study of the Lake Visovac, to our colleagues Nikola Koletić for design of the vegetation profile and Nina Vuković for critical reading. Special thanks go to the anonymous referees for improving our manuscript.

Received May 30, 2019

\section{REFERENCES}

Alegro, A., ŠEgOtA, V. \& PApP, B., 2012: Bryological research of Croatia - a historical overview. Studia botanica Hungarica 43, 5-12.

Alegro, A., Papp, B., Szurdoki, E., Šegota, V., Šapić, I. \& Vukelić, J., 2014: Contribution to the bryophytes flora of Croatia III. Plitvička jezera National Park and adjacent areas. Studia Botanica Hungarica 45, 49-65.

Alegro, A., ŠEgOtA, V. \& PAPP, B., 2015: A contribution to the bryophyte flora of Croatia IV: Žumberačka gora Mts. Studia Botanica Hungarica 46(1), 5-24.

Alegro, A., Šegota, V., Papp, B., Deme, J., Kovács, D., Purger, D. \& Csiky, J., 2018a: The invasive moss Campylopus introflexus (Hedw.) Brid. (Bryophyta) spreads further into South-Eastern Europe. Cryptogamie, Bryologie 39(3), 331-341.

Alegro, A., Šegota, V., Vuković, N. \& Papp, B., 2018b, Myurella sibirica in Croatia, new record for Southeastern Europe. Herzogia 31, 782-790.

Alegro, A., Šegota, V., Rimac, A., Kiebacher, T., Prlić, D., Sedlar, Z., Vuković, N. \& Papp. B., 2019 : New and noteworthy bryophyte records from Croatia. Cryptogamie, Bryologie 40(2), 3-11.

Alegro A. \& Šmgota V. (eds) 2019. - Bryophytes. In: Nikolić T. (ed.), Flora Croatica Database. On-Line (http://hirc.botanic.hr/fcd). Division of Botany, Faculty of Science, University of Zagreb, accessed on 1 July 2019.

AnĐić, B., Dragićević, S., Stešević, D. \& Papp, B., 2018: Fissidens fontanus, a new species to Montenegro. Lindbergia 41(1), 1-3.

Blockeel, T. L., Passos Bastos C. J., Bednarek-Ochyra, H., Ochyra, R., Dulin, M. V., Garcia, C., Hedenäs, L., Hugonnot, V., Kirmaci, M., Koponen, T., Lebouvier, M., Martins, A., Müller, F., Sabovljević, M., Lakušić, D., Schäfer-Verwimp, A., Sérgio, C., Surina, B., Yayintas, Ö. T., 2009: New national and regional bryophyte records 22. Journal of Bryologie 31, 201-210.

Boros, Á., 1968: Bryogeographie und Bryoflora Ungarns. Akadémiai Kiadó, Budapest, 466 pp.

Blockeel T.L. \& Nieuwkoop J.A.W., 2016: The Bryophyte Flora of Lesbos. Herzogia 29(1), 1-34.

CEN/TC 230, 2007: Water quality - Guidance standard for the surveying of macrophytes in lakes, 15460. European Committee for Standardization, Brussels.

Ciglenečki-Jušić, I., Ahel, M., Omanović, D., Mikac, N., Bura Nakić, E., Marguš, M., Dautović, J., CAKTAŠ ŠAGI, F., ČAnKović, M. \& BAČIĆ, N., 2015: Eutrofikacijski procesi u ekosustavu rijeke Krke - područje Visovačkog jezera. In: Biondić, D., Holjević, D. \& Vizner, M. (eds.) Hrvatske vode na investicijskom valu, $6^{\text {th }}$ Croatian Water Conference with International Partipipation, Zbornik radova-Proceedings. Opatija, 353-362.

Düll, R., Ganeva, A., Martinčič, A. \& Pavletić, Z., 1999. Contributions to the Bryoflora of former Yugoslavia and Bulgaria. IDH-Verlag Bad Münstereifel. pp. 1-200.

Ellis, L. T., Alegro, A., Bednarek-Ochyra, H., Ochyra, R., Bergamini, A., Cogoni, A., Erzberger, P., Górski, P., Gremmen, N., Hespanhol, H., Vieira, C., Kurbatova, L. E., Lebouvier, M., Martinčič, A., Asthana, A. K., Gupta, R., Nath, V., Natcheva, R., Ganeva, A., Özdemir, T., Batan, N, Plášek, V., Porley, R. D., Randić, M., Sawicki, J., Schroder, W., Sérgio, C., Smith, V. R., Sollman, P. S., Ştefănut, S., Stevenson, C. R., SuÁrez, G. M., Surina, B., Uyar, G. \& Modrić Surina, Ž., 2012a: New national and regional bryophyte records 31. Journal of bryology 34(2), 123-134.

Ellis, L. T., Aleggro, A., Bansal, P., Nath, V., Cykowska, B., Bednarek-Ochyra, H., Ochyra, R., Dulin, M. V. Erzberger, P., Garcia, C., Sérgio, C., Claro, D., Stow, S., Hedderson, T. A., Hodgetts, N. G., Hugonnot, V., Kučera, J., Lara, F., Pertierra, L., Lebouvier, M., Liepina, L., Mežaka, 
A., Strazdina, L., Madžule, L., Rēriha, I., Mazooji, A., Natcheva, R., Phephu, N., Philippov, D. A., Plášěr, V., Činal, L., Pócs, T., Porley, R. D., Sabovljević, M., Salimpour, F., Behroozmand Motlagh, M., Sharifnia, F., Akhoondi Darzikolaei, S., Schärer-Verwimp, A., Šegota, V., Shaw, A. J., Sim-Sim, M., Sollman, P., Spitale, D., Hölzer, A., Stebel, A., Váňa, J., Van Rooy, J. \& Vončina, G., 2012b: New national and regional bryophyte records 32. Journal of bryology 34(3), 231-246.

Ellis, L. T., Aleffi, M., Tacchi, R., Alegro, A., Alonso, M., Asthana, A. K., Sahu, V., Biasuso, A. B., Callaghan, D. A., Ezer, T., Kara, R., Seyli, T., Garilleti, R., Gil-López, M. J., Gwynne-Evans, D., Hedderson, T. A., Kiebacher, T., Larraín, J., Long, D., Luth, M., Malcolm, B., Mamontov, Y. S., Newsham, K. K., Nobis, M., Nowak, A., Ochyra, R., Pawlikowski, P., Pláśě, V., Čihal, L., Potemkin, A. D., Puche, F., Rios, D., Gallego, M. T., Guerra, J., Sawicki, J., Schäfer-Verwimp, A., Segarra-Moragues, J. G., Šegota, V., Sofronova, E. V., Ştefănut, S., Szúcs, P., Bidló, A., Papp, B., Szurdoki, E., Tan, B. C., Váňa, J., Vigalondo, B., Draper, I., Lara, F., Yoon, Y.-J., Sun, B.-Y. \& Nishimura, N., 2014: New national and regional bryophyte records 41. Journal of bryology 36(4), 306-324.

Ellis, L. T., Alegro, A., Šegota, V., Bakalin, V. A., Barone, R., Borovichev, E. A., Hugonnot, V., Lebouvier, M., Nobis, M., Nowak, A., Ochyra, R., Papp, B., Szurdoki, E., Piwowarczyk, R., Plášek, V., Činal, L., Ren, Z.-J., Sabovljević, M., Sérgio, C., Garcia, C. A., Melo, I., Sawicki, J., Stebel, A., ŞTefănuț, S., Ion, R., Manole, A., Tziontzis, I., Xiong, Y. \& ZhaO, Z.-T., 2015: New national and regional bryophyte records 44. Journal of bryology 37(3), 228-241.

Ellis, L. T., Aleffi, M., Alegro, A., Šegota, V., Asthana, A. K., Gupta, R., Singh, V. J., Bakalin, V. A., Bednarek-Ochyra, H., Cykowska-Marzencka, B., Benitez, A., Borovichev, E. A., Vilnet, A. A., Konstantinova, N. A., Buck, W. R., Cacciatoro, C., Sérgio, C., Csiky, J., Deme, J., Kovács, D., Damsholt, K., Enroth, J., Erzberger, P., Fedosov, V. E., Fuertes, E., Gradstein, S. R., Gremmen, N. J. M, Hallingbäck, T., Jukonienė, I., Kiebacher, T., Larraín, J., Lebouvier, M., Lüth, M., Mamontov Yu, S., Potemkin, A. D., Nemeth, Cs., Nieuwkoop, J. A. W., Nobis, M., Węgrzyn, M., Wietrzyk, P., Osorio, F., Parnikoza, I., Virchenko, V. M., Peralta, D. F., Carmo, D. M., Plášek, V., Skoupá, Z., Poponessi, S., Venanzoni, R., Puche, F., Purger, D., Reeb, C., Rios, R., RodriguezQuiel, E., Arrocha, C., Sabovljević, M., Nikolić, N., Sabovljević, A. D., Dos Santos, E. L., Segarra-Moragues, J. G., Ştefănuț, S. \& Stončius, D., 2016: New national and regional bryophyte records 48. Journal of bryology 38(3), 235-259.

Ellis, L. T., Alataş, M., Alegro, A., Šegota, V., Ozimec, S., Vuković, N., Koletić, N., Prlić, D., Bontek, M., Asthana, A. K., Gupta, R., Sahu, V., Rawat, K. K., Bakalin, V. A., Klimova, K. G., Baráth, K., Beldiman, L. N., Csiky, J., Deme, J., Kovács, D., Cano, M. J., Guerra, J., Czernyadjeva, I. V., Dulin, M. V., Erzberger, P., Ezer, T., Fedosov, V. E., Fontinha, S., Sim-Sim, M., Garcia, C. A., Martins, A., Granzow-De la Cerda, I., Sáez, L., Hassel, K., Weibull, H., Hodgetts, N. G., Infante, M., Heras, P., Kiebacher, T., Kučera, J., Lebouvier, M., Ochyra, R., Ören, M., Papp, B., Park, S. J., Sun, B.-Y., Plášek, V., Poponessi, S., Venanzoni, R., Purger, D., Reis, F., Singila, M., Stebel, A., Ştefănuț, S., Uyar, G., Vončina, G., Wigginton, M. J., Yong, K.-T., Chan, M. S. \& Yoon, Y.-J., 2017: New national and regional bryophyte records 52. Journal of bryology 39(3), 285-304.

Ellis, L. T., Afonina, O. M., Andriamiarisoa, R. L., Asthana, G., Bharti, R., Aymerich, P., Bambe, B., Boiko, M., Brugués, M., Ruiz, E., Sáez, L., Cano, M. J., Ros, R, Činal, L., Deme, J., Csiky, J., Dihoru, G., Dřevojan, P., Ezer, T., Fedosov, V. E., E. Ignatova, A., Seregin, A. P., Garcia, C. A., Martins, A., Sérgio, C., Sim-Sim, M., Rodrigues, A. S. B., Gradstein, S. R., Reeb, C., Irmah, A., Suleiman, M., Koponen, T., Kučera, J., Lebouvier, M., LiQun, Y., Long, D. G., Maksimov, A. I., Maksimova, T. A., Muñoz, J., Nobis, M., Nowak, A., Ochyra, R., O’Leary, S. V., Osorio, F., Pisarenko, O. Yu., Plášek, V., Skoupá, Z., Schäfer-Verwimp, A., Schnyder, N., Shevock, J. R., Ştefănuț, S., Sulayman, V, Sun, B.-Y., Park, S. J., Tubanova, D. Ya., Vánă, J., Wolski, G. J., Yao, K.-Y., Yoon, Y-J, Yücel, E., 2018: New national and regional bryophyte records 56. Journal of bryology 40(3), 271-296.

Erzberger, P., 2016: The genus Fissidens (Fissidentaceae, Bryophyta) in Hungary. Studia botanica Hungarica 47(1), 41-139.

Frey, W., Frahm, J.-P., Fische, E. \& Lobin, W., 2006: The liverworts, mosses and ferns of Europe. Harley Books, Colchester.

Hill, M. O. \& Preston, C. D., 1998: The geographical relationships of British and Irish bryophytes. Journal of bryology 20, 127-226.

Hodgetts, N. G., 2015: Checklist and country status of European bryophytes - towards a new Red List for Europe. Irish Willife Manuals No. 84. National Parks and Wildlife Services, Department of Arts, Heritage and the Gaeltacht. Ireland. 
Hübschmann, A., 1986: Prodromus der Moosgesellschaften Zentraleuropas. Bryophyt. Bibl. 32, 1-413.

IUCNStandards and Petitions Subcommittee, 2017: Guidelines for Using theIUCNRed List Categories and Criteria. Ver. 13. On-Line (http://www.iucnredlist.org/documents/RedListGuidelines.pdf.). Standards and Petitions Subcommittee., accessed on 1 July 2019.

Köckinger, H., Kučera, J., Hofmann, H., Müller, N. \& Amann G., 2012: Barbula consanguinea (Thwaites \& Mitt.) A. Jaeger, discovered in Switzerland and Austria, with a revision of former European records of B. indica (Hook.) Spreng. Herzogia 25(1), 61-70.

Martinčič A., 2003: Seznam lisnatih mahov (Bryopsida) Slovenije. Hacquetia 2(1): 91-166.

Mihaljević, Z., Kerovec, M., Ternjej, I. \& Mrakovčić, M., 2001: Composition and depth distribution of oligochaete fauna of Mediterranean karstic lake (Lake Visovac, Croatia). Biologia 56, 461-467.

Natcheva, R., Ganeva, A. \& Spiridonov, G., 2006: Red list of the bryophytes in Bulgaria. Phytologia Balcanica 12(1), 55-62.

Nebel, M. \& Philipri, G. (eds.), 2000. Die Moose Baden-Württembergs Band 1. - Stuttgart: Ulmer.

Neumayr, L., 1971: Moosgesellschaften der südöstlichen Frankenalb und des Vorderen Bayerischen Waldes. Hoppea, Denkschriften der Regensburgischen Botanischen Gesellschaft 29(1-2), 1-364.

Papp, B. \& Sabovljević, M., 2009: Notes on some new and interesting bryophyte records from Croatia. Journal of bryology 31, 272-275.

Papp, B., Alegro, A., Šmgota, V., ŠApić, I. \& Vukelić, J., 2013a: Additions to the bryophyte flora of Croatia. Journal of bryology 35(2), 140-143.

PApp, B., Alegro, A., Šegota, V., ŠApić, I. \& Vukelić, J., 2013b: Contribution to the bryophyte flora of Croatia II. The Northern Velebit. Studia botanica Hungarica 44, 213-228.

PApP, B., Alegro, A., ŠEgota, V., ŠApić, I. \& VuKelić, J., 2013c: Contribution to the bryophyte flora of Croatia I. Gorski kotar Region (W Croatia). Studia botanica Hungarica 44, 193-211.

Privitera, M. \& Puglisi, M.. 1994: Octodiceras fontanum (Musci): a new record from Sicily. Flora Mediterranea 4, 171-174.

ReŠETNIK, I. \& ŠEGOTA, V. (eds.), 2018: Virtual herbarium ZA \& ZAHO. On-Line (http:// herbariumcroaticum.biol.pmf.hr) Division of Botany, Faculty of Science, University of Zagreb, accessed on 1 July 2019.

Ros, R. M., Mazimpaka, V., Abou-Salama, U., Aleffi, M., Blockeel, T. L., Brugués, M., Cros, R. M., Dia, M., G., Dirkse, G. M., Draper, I., El-Saadawi, W., Erda Ğ, A., Ganeva, A., Gabriel, R., González-Mancebo, J. M., Granger, C., Herrnstadt, I., Hugonot, V., Khalili, K., Kürschner, H., Losada-Lima, A., Luis, L., Mifsud, S., Privitera, M., Puglisi, M., Sabovljević, M., Sérgio, C., Shabbara, H., Sim-Sim, M., Sotiaux, A., Tacchi, R., Vanderpoorten, A., Werner, O., 2013: Mosses of the Mediterranean, an annotated checklist. Cryptogamie Bryologie 34, 99-283.

Sabovljević, M., Natcheva, R., Dihoru, G., Tsakiri, E., Dragićević, D., ErdaĞ, A. \& Papp, B., 2008 : Check-list of the mosses of SE Europe. Phytologia Balcanica 14(2), 207-244.

Sabovljević, M., Alegro, A., Sabovljević, A., Marka, J. \& Vujičić, M., 2011: An insight into diversity of the Balkan Peninsula bryophyte flora in the European background. Revue d'ecologie (Terre et vie) 66, 399-413.

Sabovljević, M., Kuzmanović, N., Vreš, B., Ruščić, M. \& Surina, B., 2018: Contribution to the bryophyte flora of the island of Rava (Adriatic Sea, Mediterranean) and Zygodon conoideus new to Croatia. Herzogia 31(2), 998-994.

Sмith, A. J. E., 2004: The Moss Flora of Britain and Ireland. Cambridge University Press.

StefăNUȚ, S. \& Goia, I., 2012: Checklist and Red List of Bryophytes of Romania. Nova Hedwigia 95(12), 59-104.

Stelzer, D. \& SChNeider, S., 2001: Ökologische Bewertung mit Makrophyten - Kartierungsmethoden für Seen. In: Deutsche Gesellschaft für Limnologie (DGL) (ed.), Tagungsbericht 2000 (Magdeburg), Tutzing, 91-95.

Špoljar, M., Habdija, I., Primc-Habdija, B. \& Šipoš, L., 2005: Impact of Environmental Variables and Food Availability on Rotifer Assemblage in the Karstic Barrage Lake Visovac (Krka River, Croatia). Internation review of Hydrobiology 90(5-6), 555-579.

Thiers, B. 2019: Index Herbariorum: A Global Directory of Public Herbaria and Associated Staff. New York Botanical Garden, New York, http://sweetgum.nybg.org/science/ih/, accessed on 2 July 2019. 
